\title{
Badania hydrorafinatów z procesu współuwodornienia w zakresie oznaczania zawartości mono- i diacylogliceroli
}

\section{The research on hydro-raffinates from the co-hydrogenation process in terms of mono- and diacylglycerols content determination}

\author{
Zygmunt Burnus, Agnieszka Wieczorek \\ Instytut Nafty i Gazu - Państwowy Instytut Badawczy
}

\begin{abstract}
STRESZCZENIE: W niniejszej pracy zbadano możliwości wykorzystania techniki chromatografii gazowej GC-FID do badania zawartości mono- i diacylogliceroli w strumieniu z procesu współuwodornienia oleju rzepakowego i średnich destylatów naftowych. Produkty z tego procesu planuje się w przyszłości coraz szerzej wykorzystywać jako nowy biokomponent paliwa do silników o zapłonie samoczynnym. Przed wprowadzeniem nowego rodzaju komponentów do paliw konieczne jest wykonanie na nich szczegółowych badań, szczególnie pod kątem pozostałości surowca tłuszczowego. Rozporządzenie Ministra Klimatu z dnia 24 czerwca 2020 r. w sprawie zawartości biokomponentów powstałych w wyniku współuwodornienia zawiera wytyczne określania poziomu przereagowania biomasy na podstawie zawartości triacylogliceroli w hydrorafinacie. Stąd - na podstawie oznaczenia zawartości triacylogliceroli - możliwa jest ocena prawidłowości zachodzenia procesu współuwodornienia. Jednakże w produkcie z tego procesu mogą być również obecne inne składniki tłuszczowe w formie nieprzereagowanych pozostałości. Uzasadnione wydaje się zatem przeprowadzenie badań innych składników śladowych pochodzenia tłuszczowego w hydrorafinacie ze względu na wprowadzanie do procesu współuwodornienia zróżnicowanych surowców roślinnych wraz z węglowodorami pochodzenia naftowego. Z uwagi na brak dostępnych metodyk znormalizowanych badania tego typu produktów dokonano przeglądu literatury w zakresie możliwości zastosowania technik analitycznych, obejmujących chromatografię gazową i cieczową, do badania tzw. mono- i diacylogliceroli, stanowiących pozostałości surowca tłuszczowego, w różnego rodzaju matrycach, w tym w olejach roślinnych i w estrach metylowych kwasów tłuszczowych. W przypadku badania zawartości mono- i diacylogliceroli w produkcie z procesu współuwodornienia konieczne było zastosowanie wstępnego oczyszczania oznaczanych składników techniką klasycznej chromatografii cieczowej. Technika ta umożliwia oddzielenie matrycy próbki i zatężenie oznaczanych składników przed analizą techniką chromatografii gazowej. Z uwagi na skomplikowaną matrycę próbek i niski wymagany poziom oznaczalności konieczne jest dobranie odpowiednich warunków usuwania matrycy techniką klasycznej chromatografii cieczowej. W tym celu opracowano metodykę własną badania zawartości mono- i diacylogliceroli w hydrorafinacie, którą wykorzystano do badań wybranych próbek rzeczywistych hydrorafinatów z procesu współuwodornienia co-HVO i HVO. Wskazano na możliwość wykrywania tych śladowych składników tłuszczowych na niskim poziomie zawartości - już od $2 \mathrm{mg} / \mathrm{kg}$. Uzyskano wysoką czułość metody, która pozwoliła na dodatkową ocenę jakościową tego rodzaju produktów z procesów współuwodornienia, które stopniowo zyskują na znaczeniu na europejskim rynku paliw płynnych.
\end{abstract}

Słowa kluczowe: hydrorafinat, współuwodornienie, chromatografia gazowa, acyloglicerole.

ABSTRACT: In this work, the possibilities of using the GC-FID gas chromatography technique for determination of mono- and diacylglycerols content in the stream from the co-hydrogenation of rapeseed oil and middle distillates were investigated. Products from this process are planned to be increasingly used in the future as a new biocomponent of fuel for diesel engines. Before introducing new types of fuel components, it is necessary to test them in detail, especially in terms of residues of the fat raw material. The Regulation of the Minister of Climate of June 24, 2020 on the content of biocomponents formed as a result of co-hydrogenation indicates that the level of biomass conversion is determined on the basis of the content of triacylglycerols in the hydro-raffinate. Hence, on the basis of this determination, it is possible to assess the correctness of the co-hydrogenation process. However, other fatty components may be present in the product of this process in the form of unreacted residues. Therefore, it seems justified to carry out studies on other trace components of fatty origin in the hydro-treating material, due to the introduction of various plant materials together with petroleum hydrocarbons into the co-hydrogenation process. Due to the lack of available standardized methodologies for testing this type of products, a review of the literature was made regarding the possibility of using analytical techniques including gas and liquid chromatography to determine content of the so-called mono- and dicylglycerols, being residues of the fatty raw material, in various types of matrices,

Autor do korespondencji: Z. Burnus, e-mail: zygmunt.burnus@inig.pl

Artykuł nadesłano do Redakcji: 13.01.2021 r. Zatwierdzono do druku: 08.06.2021 r. 
including vegetable oils and fatty acid methyl esters. In the case of examining the content of mono- and diacylglycerols in the product from the co-hydrogenation process, it was necessary to use the technique of liquid chromatography for the first-step concentration of the substances of interest. This technique made it possible to separate the sample matrix and concentrate the components to be determined prior to gas chromatographic analysis. Due to the complicated matrix of samples and the low required level of quantification, it was necessary to select appropriate conditions for removing the matrix using the classical liquid chromatography technique. A proprietary methodology for testing the content of mono- and diacylglycerols in the hydro-raffinate was developed, which was used to test selected samples of real hydro-raffinates from the co-HVO and HVO co-hydrogenation process. The ability to detect these trace fat components at a low level was indicated - as low as $2 \mathrm{mg} / \mathrm{kg}$. The obtained sensitivity of the method allowed for additional qualitative assessment of this type of co-hydrogenation products, which are gradually gaining importance on the European market of liquid fuels.

Key words: hydro-raffinate, co-hydrogenation, gas chromatography, acylglycerols.

\section{Wstęp}

W 2019 roku w Instytucie Nafty i Gazu - Państwowym Instytucie Badawczym zrealizowano pracę (Burnus, 2019), w ramach której opracowano metodę oznaczania śladowych zawartości składników lipidowych, takich jak wolne kwasy thuszczowe (WKT) oraz triacyloglicerole (TAG), w produktach z procesu współuwodornienia.

Proces współuwodornienia, który można zapisać w skrócie jako „co-HVO”, wywodzi się z procesu HVO (ang. hydrotreated vegetable oil), opracowanego i opatentowanego przez Neste Oil (Finlandia) pod nazwą NExBTL, wdrożonego do praktyki przemysłowej w 2007 roku. W procesie HVO, jak i co-HVO zachodzi hydrokonwersja triacylogliceroli zawartych w olejach roślinnych do węglowodorów, które mogą być wykorzystane jako komponent paliwa do silników o zapłonie samoczynnym (Jakkula et al., 2004; Mylloya et al., 2007; Lubowicz 2016). Badania nad tym procesem były prowadzone również w Instytucie od roku 2009 (Jęczmionek i Lubowicz, 2009; Jęczmionek, 2011). Procesy prowadzi się w obecności wodoru, przy użyciu katalizatorów typu $\mathrm{NiMo} / \mathrm{Al}_{2} \mathrm{O}_{3}$ lub $\mathrm{CoMo} / \mathrm{Al}_{2} \mathrm{O}_{3}$. Trzy możliwe ścieżki reakcji: 1) hydroodtlenienie i uwodornienie; 2) dekarboksylacja i uwodornienie lub mało prawdopodobna ścieżka 3) dekarbonylacja i uwodornienie prowadzą do powstania różnego rodzaju węglowodorów (głównie izo- i n-parafinowych) o zakresie temperatury wrzenia średniego destylatu. Do produktów ubocznych należą: propan, $\mathrm{CO}_{2}$ i woda. $\mathrm{W}$ procesie $\mathrm{HVO}$ jako wsad stosuje się czysty surowiec thuszczowy, natomiast w procesie współuwodornienia co-HVO do strumienia średniego destylatu podawany jest w sposób ciągły surowiec thuszczowy w określonej ilości (kilku lub więcej procent wsadu).

Konieczność badania składników śladowych pochodzenia tłuszczowego wynika $\mathrm{z}$ faktu wprowadzania do procesu współuwodornienia surowca roślinnego wraz z węglowodorami pochodzenia naftowego. $\mathrm{W}$ związku $\mathrm{z}$ tym $\mathrm{w}$ strumieniu po procesie należy ocenić zawartość nieprzereagowanych składników tłuszczowych. Za bezpieczny poziom zawartości substancji nieprzereagowanych $\mathrm{w}$ strumieniu po procesie uważa się zawartość poniżej $10-20 \mathrm{mg} / \mathrm{kg}$. Ten poziom oznacza nie- mal całkowite przereagowanie surowca roślinnego w procesie współuwodornienia co-HVO lub HVO, co umożliwia ocenę prawidłowości działania całego procesu.

Rozporządzenie Ministra Klimatu z dnia 24 czerwca 2020 r. w sprawie zawartości biokomponentów powstałych w wyniku współuwodornienia (Dz.U. z 2020 r. poz. 1141) opisuje sposób oceny poziomu przereagowania biomasy na podstawie zawartości triacylogliceroli w hydrorafinacie (strumień z procesu co-HVO), przy czym maksymalny poziom ich zawartości ustalono na $10 \mathrm{mg} / \mathrm{kg}$.

Poza głównymi składnikami tłuszczów i olejów roślinnych, takimi jak TAG, które stanowią najczęściej ponad 95\% ( $\mathrm{m} / \mathrm{m})$ surowca roślinnego, oraz WKT (od śladowych zawartości do kilkunastu procent), są w nich również obecne na poziomie zwykle poniżej 0,5-1,0\% składniki takie jak monoacyloglicerole i diacyloglicerole. Wskazane jest zatem wykonanie badań produktów pochodzących ze strumieni z procesu współuwodornienia co-HVO oraz z procesu HVO pod kątem zawartości monoacylogliceroli i diacylogliceroli.

Na podstawie doświadczeń Instytutu Nafty i Gazu Państwowego Instytutu Badawczego można stwierdzić, że oznaczenie TAG na poziomie poniżej $10 \mathrm{mg} / \mathrm{kg}$ wymaga zastosowania techniki chromatografii gazowej z detekcją płomieniowo-jonizacyjną FID i kolumny o wysokiej odporności termicznej fazy stacjonarnej, natomiast oznaczenie zawartości WKT na poziomie poniżej $5 \mathrm{mg} / \mathrm{kg}$ możliwe jest dzięki zastosowaniu techniki chromatografii cieczowej w połączeniu z chromatografią gazową ze spektrometrią mas GC-MS (Burnus, 2019).

Oznaczenie w średnim destylacie tak niskich zawartości monoacylogliceroli i diacylogliceroli (poniżej $10 \mathrm{mg} / \mathrm{kg}$ ) stanowi duże wyzwanie analityczne $\mathrm{z}$ uwagi na pokrywanie się zakresów temperatury wrzenia monoacylogliceroli z zakresem typowym dla średnich destylatów naftowych. Oznaczenie wymienionych substancji wykonuje się dla FAME metodą znormalizowaną według PN-EN 14105:2012 (odpowiednik w USA: ASTM D6584-17), jednak z niewystarczającą granicą oznaczalności dla monoacylogliceroli i diacylogliceroli, określoną w normie PN-EN jako $1000 \mathrm{mg} / \mathrm{kg}$, a w normie ASTM odpowiednio jako $90 \mathrm{mg} / \mathrm{kg}$ oraz $923 \mathrm{mg} / \mathrm{kg}$ dla monoacylogli- 
ceroli i diacylogliceroli. W przypadku badania próbek FAME pod kątem zawartości mono- i diacylogliceroli oznaczenie nie jest problematyczne, ponieważ uzyskuje się zadowalający rozdział pomiędzy tymi substancjami a składnikami FAME przy zastosowaniu techniki chromatografii gazowej GC-FID.

W przypadku badania zawartości mono- i diacylogliceroli w produkcie z procesu współuwodornienia - konieczne jest zastosowanie dodatkowo techniki chromatografii cieczowej dla oddzielenia matrycy próbki i zatężenia składników przed analizą techniką chromatografii gazowej. Z uwagi na skomplikowaną matrycę próbek i niski wymagany poziom oznaczalności konieczne jest dobranie odpowiednich warunków usuwania matrycy techniką klasycznej chromatografii cieczowej.

\section{Budowa i właściwości fizykochemiczne mono- i diacylogliceroli}

Monoacyloglicerole występujące w olejach roślinnych i thuszczach stanowią pod względem struktury chemicznej cząsteczkę glicerolu z przyłączoną poprzez atom tlenu jedną resztą kwasu tłuszczowego. Biorąc pod uwagę, że w Polsce do produkcji FAME wykorzystywany jest głównie olej rzepakowy, monoacyloglicerole obecne w handlowych próbkach FAME będą stanowić głównie trzy związki organiczne:

- monooleinian glicerolu (C18:1);

- monopalmitynian glicerolu (C16:0);

- monostearynian glicerolu (C18:0).

Na rysunku 1 przedstawiono budowę strukturalną jednego z wymienionych monoacylogliceroli z podstawnikiem C18:0.

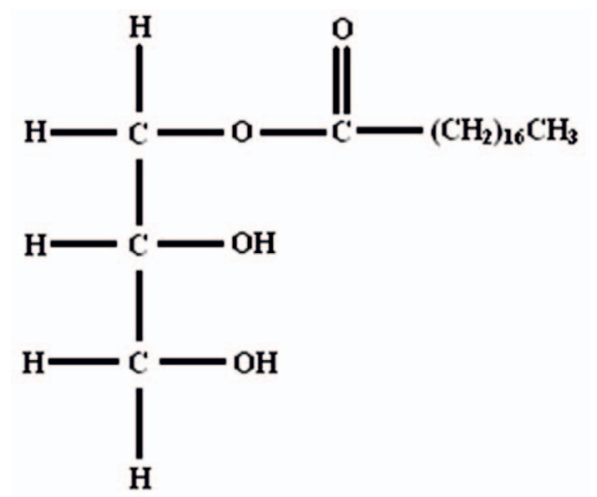

Rys. 1. Budowa strukturalna 1-monostearynianu glicerolu

Fig. 1. Molecular structure of glicerol 1-monostearate

Formy nasycone monoacylogliceroli charakteryzują się podwyższoną temperaturą topnienia (około $50-60^{\circ} \mathrm{C}$ ) względem form nienasyconych (około $30^{\circ} \mathrm{C}$ ) (Chemical Book: Glyceryl Monooleate; Glyceryl Monostearate).

Diacyloglicerole występujące w olejach roślinnych i tłuszczach pod względem struktury chemicznej składają się z cząsteczki glicerolu z przyłączonymi poprzez atom tlenu dwiema resztami kwasu tłuszczowego w pozycji 1,3- lub 1,2-. Skład kwasów tłuszczowych dla typowego oleju rzepakowego warunkuje obecność głównie jednego diacyloglicerolu: 1,3-dioleinianu glicerolu (C18:1), o 36 atomach węgla w podstawnikach kwasów tłuszczowych, ale również niewielkich ilości diacylogliceroli posiadających 34 lub 38 atomów węgla w podstawnikach.

Na rysunku 2 przedstawiono budowę strukturalną jednego z wymienionych diacylogliceroli z podstawnikiem C18:1.

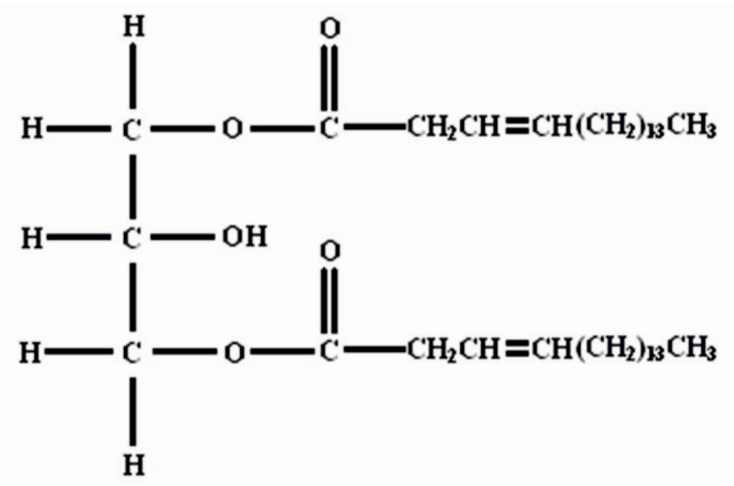

Rys. 2. Budowa strukturalna 1,3-dioleinianu glicerolu

Fig. 2. Molecular structure of glicerol 1,3-dioleate

Podobnie jak w przypadku monoacylogliceroli formy nasycone diacylogliceroli charakteryzują się podwyższoną temperaturą topnienia (około $80^{\circ} \mathrm{C}$ ) względem form nienasyconych (około $20^{\circ} \mathrm{C}$ ) (Chemical Book: 1,3-Diolein; 1,3-Distearin).

\section{Metody oznaczania mono- i diacylogliceroli}

Zarówno zawartość monoacylogliceroli, jak i diacylogliceroli to parametry oznaczane podczas badania jakości biopaliw i biokomponentów zgodnie z odpowiednimi rozporządzeniami Ministra Energii (Dz.U. z 2016 r. poz. 771; Dz.U. z 2016 r. poz. 1802) dotyczącymi wymagań jakościowych i metod badań. Matrycę próbki stanowią estry metylowe kwasów tłuszczowych FAME, a do oznaczania mono- i diacylogliceroli wykorzystywana jest norma PN-EN 14105:2012. W wymienionej normie podany jest sposób oznaczania monoacylogliceroli - zarówno tych nasyconych, jak i nienasyconych oraz diacylogliceroli. Rozdział pomiędzy pikami monoacylogliceroli i diacylogliceroli a pikami poszczególnych FAME jest zapewniony poprzez kolumnę chromatograficzną. Łatwość rozdziału wynika z niewielkiego stopnia skomplikowania składu estrów metylowych kwasów tłuszczowych FAME, składających się głównie z estru metylowego kwasu oleinowego, stearynowego, palmitynowego, linolowego i linolenowego oraz mniejszych ilości estrów kwasów tłuszczowych o długości łańcucha węglowego od 20 do 24 atomów węgla. 
W przypadku matrycy typu hydrorafinatu z procesu współuwodornienia co-HVO mamy do czynienia z mieszaniną węglowodorów parafinowych, naftenowych i aromatycznych o długości atomów węgla w cząsteczce od 8 do 26 . Węglowodory te występują w hydrorafinacie w postaci różnych odmian strukturalnych, których liczba przekracza wartość kilku tysięcy. Chromatografia gazowa z wykorzystaniem pojedynczej kolumny chromatograficznej nie jest w stanie sprostać zadaniu rozdzielenia takiej mieszaniny, w tym celu konieczne jest zastosowanie chromatografii dwuwymiarowej. Nie ma również możliwości bezpośredniego wykorzystania chromatografii gazowej w warunkach opisanych w normie PN-EN 14105:2012 do badania próbek hydrorafinatów pod kątem zawartości mono- i diacylogliceroli na poziomie $10 \mathrm{mg} / \mathrm{kg}$, ponieważ zachodzi pokrywanie się pików matrycy hydrorafinatu z pikami mono- i diacylogliceroli.

Spośród innych dostępnych metod znormalizowanych dotyczących oznaczania acylogliceroli należy wymienić normę PN-EN ISO 18395:2008, która dotyczy oznaczania monoacylogliceroli, diacylogliceroli, triacylogliceroli i glicerolu metodą wysokosprawnej chromatografii sitowej w olejach i tłuszczach roślinnych oraz zwierzęcych. Metoda ma zastosowanie do emulgatorów, które zawierają powyżej 10\% monoacylogliceroli, diacylogliceroli. Technika wysokosprawnej chromatografii sitowej jest bardzo dobrą techniką rozdziału takiej mieszaniny związków organicznych, nie cechuje się jednak zbyt dużą czułością. Przeważnie nie jest możliwe oznaczanie za jej pomocą substancji na poziomie zawartości poniżej $0,1 \%(\mathrm{~m} / \mathrm{m})$.

Drugą normą dostępną w zbiorze norm polskich jest dokument PN-EN ISO 29822:2014-06. Norma ta dotyczy oznaczania względnych ilości 1,2- i 1,3-diacylogliceroli w olejach i tłuszczach roślinnych. 1,2-diacyloglicerole obecne w olejach i tłuszczach są niestabilne i w czasie ich przechowywania ulegają przemianie do stabilnych 1,3-diacylogliceroli. Oznaczenie tych pierwszych służy do oceny jakości olejów i tłuszczów roślinnych. Metoda polega na wydzieleniu frakcji zawierającej diacyloglicerole przy użyciu kolumny wypełnionej żelem krzemionkowym. Frakcja ta jest następnie poddawana działaniu czynnika MSTFA celem przeprowadzenia diacylogliceroli w bardziej lotne pochodne silanowe do analizy techniką chromatografii gazowej. Metoda dotyczy jedynie olejów i thuszczów roślinnych, o stosunkowo wysokiej zawartości diacylogliceroli, i nie nadaje się do bezpośredniego zastosowania do badania śladowych zawartości diacylogliceroli w hydrorafinacie z procesu co-HVO. Interesującą możliwością podaną w metodzie jest wydzielenie frakcji zawierającej diacyloglicerole przy użyciu żelu krzemionkowego.

W wyniku przeglądu literatury dotyczącej oznaczania monoi diacylogliceroli należy stwierdzić, że szczególnie często wykorzystuje się zmodyfikowane stanowiska badawcze, bazując na wytycznych podanych w normie PN-EN 14105:2012 lub ASTM D6584-17. Do kluczowych, powtarzających się elementów stanowisk badawczych należy zaliczyć kolumnę z niepolarną fazą stacjonarną typu metylopolisiloksan, typu wysokotemperaturowego, dozownik on-column lub PTV oraz detektor płomieniowo-jonizacyjny FID. Podobny zestaw zastosowano w pracy Flanagan et al. (2019) z tą różnicą, że dodatkowo na wylocie kolumny chromatograficznej wykorzystano splitter, umożliwiający podłączenie do spektrometru mas celem dokładniejszej identyfikacji poszczególnych acylogliceroli. Uzyskano wysoką czułość dla oznaczania acylogliceroli poniżej $1 \mathrm{mg} / \mathrm{kg}$ przy zastosowaniu reaktora krakingu dla próbki oleju sojowego. Tak skomplikowany układ analityczny najprawdopodobniej nie nadawałby się do badania próbek hydrorafinatów z procesu co-HVO. Węglowodory obecne w próbce musiałyby być usunięte przed oznaczeniem z uwagi na zastosowaną kolumnę chromatograficzną i koelucję acylogliceroli i węglowodorów, która uniemożliwiłaby oznaczenie techniką GC-FID oraz znacząco obniżyłaby czułość zastosowanego spektrometru mas.

Praca Alleman et al. (2019) dotyczyła możliwości ulepszenia metody oznaczania glicerolu i acylogliceroli według normy ASTM D6584-17 w zakresie poprawy dokładności oznaczania monoacylogliceroli. Wskazano na możliwość występowania w biopaliwach monoacylogliceroli innych niż o 16 i 18 atomach węgla w cząsteczce, typowych w przypadku zastosowania jako surowiec oleju rzepakowego lub sojowego. Autorzy wykorzystali zestaw wzorców monoacylogliceroli o długości atomów węgla w podstawniku kwasu tłuszczowego od C10 do C24. Z doświadczenia Instytutu Nafty i Gazu - Państwowego Instytutu Badawczego wynika, że monoacyloglicerole o podstawnikach kwasów tłuszczowych innych niż 16 i 18 atomów węgla praktycznie nie są wykrywalne w FAME w przypadku zastosowania oleju rzepakowego jako surowca do produkcji FAME. Taki właśnie olej obecnie wykorzystuje się w produkcji hydrorafinatów w procesie współuwodornienia co-HVO. Autorzy zastosowali jednak kolumnę chromatograficzną o podobnej długości i fazie stacjonarnej, jak podana w normie ASTM D6584-17, bez poprawy rozdziału pomiędzy pikami monoacylogliceroli, z zachodzącą koelucją z pozostałymi głównymi i śladowymi składnikami FAME. Wykonane badania wskazują jednak na problem z występowaniem innych monoacylogliceroli w przypadku zastosowania nietypowego surowca do produkcji FAME.

W badaniach Alberdiego-Cedeño et al. (2017) opracowano metodę oznaczania szeregu trudno lotnych składników olejów roślinnych, między innymi monoacylogliceroli. Wskazano na przydatność przygotowania próbek metodą wstępnej ekstrakcji do fazy stałej SPE przed analizą metodą chromatografii gazowej ze spektrometrią mas GC-MS. Czas ekstrakcji 
wyniósł 45 min, a w metodzie GC-MS zastosowano długą kolumnę chromatograficzną $(60 \mathrm{~m}) \mathrm{z}$ filmem fazy stacjonarnej o niskiej polarności (HP-5MS), która umożliwia rozdział pomiędzy monoacyloglicerolami, jednak nie pozwala na wykrywanie diacylogliceroli z uwagi na zbytnią grubość filmu fazy stacjonarnej. Bardzo dobry rozdział pomiędzy poszczególnymi monoacyloglicerolami na długiej kolumnie skutkuje przeważnie pogorszeniem parametru wartości granicy oznaczalności badanych substancji. Dodatkowo autorzy przedstawili wyniki badań jedynie jako sygnał z detektora MS, bez odniesienia się do stężeń badanych substancji, bez możliwości oceny granicy oznaczalności.

W pracy Tenga et al. (2019) do badania mono-, di- i triacylogliceroli zastosowano ekstrakcję do fazy stałej SPE połączoną z wysokosprawną chromatografią cieczową HPLC oraz wielowymiarową spektrometrią mas. Konieczność użycia aż trzech technik analitycznych związana była ze skomplikowaną matrycą badanych próbek thuszczu mlecznego, co wykazano we wcześniejszych badaniach (Zhou et al., 2014). Najniższe oznaczane stężenie mono- i diacylogliceroli wyniosło $10 \mathrm{mg} / \mathrm{kg}$. Zastosowano aż trzy różne procedury wydzielania techniką SPE przy wykorzystaniu zestawów kartridżów SPE z wypełnieniem o różnej polarności: na bazie czystej krzemionki oraz krzemionką modyfikowaną grupami $\mathrm{NH}_{2}$. Eluowanie mono- i diacylogliceroli z SPE z żelem krzemionkowym wymagało zastosowania wysokopolarnych rozpuszczalników, takich jak kwas octowy (jako dodatek 1\% do fazy ruchomej) i czysty metanol. Zastosowanie silnie polarnych rozpuszczalników związane było z faktem, że w kartridżu SPE żel krzemionkowy jest silnie aktywowany.

W pracy Ashrafa-Khorassaniego et al. (2015) zastosowano z kolei technikę ultrasprawnej chromatografii fluidalnej w stanie nadkrytycznym (UHPSFC) do oznaczania mono-, di- i triacylogliceroli w próbkach paliwa typu 100\% FAME. Podkreślono możliwość badania wszystkich acylogliceroli bez konieczności ich derywatyzacji. Dodatkowo badaniom poddano próbki syntetycznych biopaliw, w przypadku których konieczne było zastosowanie etapu oczyszczania przy użyciu żelu krzemionkowego i rozpuszczalników o zróżnicowanej polarności. Granica oznaczalności wyniosła $200 \mathrm{mg} / \mathrm{kg}$, co jest wystarczające do badania jakości FAME, jednak niewystarczające do wykonywania oznaczeń dla próbek hydrorafinatu.

W pracy Destaillatsa et al. (2010) przedstawiono możliwość oznaczania stereoizomerów (związki o tym samym wzorze strukturalnym, lecz innym ułożeniu w przestrzeni) poszczególnych nienasyconych monoacylogliceroli przy użyciu techniki chromatografii gazowej ze spektrometrią mas GC-MS. Zastosowano jedynie wykrywanie jonów charakterystycznych na podstawie widm masowych, ponieważ materiały wzorcowe stereoizomerów $\beta$-monoacylogliceroli nie są dostępne. Izomery te szybko ulegają przemianie do izomerów $\alpha$-monoacylogliceroli (odmiana stabilna).

Z kolei w pracy Zhu et al. (2013) opisano możliwość badania izomerów 1,2-diacylogliceroli w olejach roślinnych przy zastosowaniu techniki chromatografii gazowej ze spektrometrią mas z pułapką jonową. Jako technikę oczyszczania próbki i zatężania badanych substancji wykorzystano ekstrakcję do fazy stałej SPE z żelem krzemionkowym oraz sekwencją rozpuszczalników o rosnącej polarności. Diacyloglicerole były eluowane z kolumienki SPE przy użyciu eteru etylowego. Wykorzystana kolumna o długości $30 \mathrm{~m}$ z cienkim filmem fazy stacjonarnej o grubości $0,1 \mu \mathrm{m}$ umożliwiła prawidłową elucję diacylogliceroli przy zastosowaniu izotermy początkowej $200^{\circ} \mathrm{C}$ w programie temperaturowym termostatu.

Oznaczanie diacylogliceroli jest również możliwe z wykorzystaniem wysokosprawnej chromatografii cieczowej HPLC $\mathrm{z}$ detekcją mas w trybie jonizacji chemicznej pod ciśnieniem atmosferycznym (APCI - ang. atmospheric pressure chemical ionization). Holcapek et al. (2003) przebadali 16 próbek różnych olejów roślinnych przy zastosowaniu dozowania po rozcieńczeniu próbki do systemu połączonych szeregowo kolumn HPLC o wypełnieniu C18. W pracy tej wykorzystano jedynie materiały wzorcowe triacylogliceroli, nie stosując niezbędnych wzorców diacylogliceroli, nie odniesiono się do efektów matrycowych, nie podano również parametrów takich jak granica oznaczalności. Praca przedstawia chromatogramy HPLC dla oleju rzepakowego przy użyciu typowego wypełnienia kolumny $\mathrm{C} 18$, które mogą być przydatne podczas badań laboratoryjnych w ocenie porównawczej kolejności elucji z kolumny chromatograficznej.

W innej pracy (Prados et al., 2012) podjęto próbę połączenia dwóch oznaczeń w pojedyncze oznaczenie - tzn. połączenia metody oznaczania glicerolu i acylogliceroli według PN-EN 14105:2012 oraz oznaczania sumarycznej zawartości estrów i estru metylowego kwasu linolenowego według wycofanej normy PN-EN 14103:2004. Zastosowano sposób przygotowania próbki zbliżony do normy PN-EN 14105:2012 oraz wzorzec wewnętrzny do sumarycznej zawartości estrów - ester metylowy kwasu trikozanowego C23, analogiczny jak w normie PN-EN 15779+A1:2013-12 (dotyczącej oznaczania wielonienasyconych estrów metylowych kwasów tłuszczowych w FAME). Użyto dłuższej kolumny niż podana w normie PN-EN 14105:2012, tj. 25 m, oraz filmu fazy stacjonarnej z dodatkiem $5 \%$ fenylopolisiloksanu dla poprawy selektywności rozdziału badanych substancji. Przebadano FAME z różnych olejów roślinnych, w tym estry metylowe kwasów tłuszczowych FAEE. Chromatogramy wskazują na bardzo dobry rozdział pomiędzy poszczególnymi pikami mono- i diacylogliceroli oraz składnikami FAME, nie wzięto jednak pod uwagę zawartości innych składników śladowych FAME, które mogą zakłócać oznaczenie. 
Długość kolumny chromatograficznej oraz grubość filmu fazy stacjonarnej zastosowane w pracy wydają się obiecujące do wykorzystania w badaniu próbek hydrorafinatów, jednak konieczne byłoby usunięcie matrycy węglowodorowej i poprawa rozdziału poprzez użycie bardziej polarnego filmu kolumny chromatograficznej dla poprawy selektywności względem składników śladowych pochodzenia roślinnego.

Kolumnę chromatograficzną ze szczególnie interesującą fazą stacjonarną (Rtx-65TG) zastosowano w pracy z roku 2020 (Gomez-Coca et al., 2020). Poddano w niej badaniom próbki oliwy z oliwek extra virgin celem wykrycia fałszowania jej oliwą z oliwek rafinowaną w warunkach łagodnej dezodoryzacji, która jest szczególnie trudna do wykrycia. Takie badania prowadzi się dla różnych olejów roślinnych od lat 90 . ubiegłego stulecia (Perez-Camino et al., 1996). W badaniach fałszerstw oliwy wykorzystuje się obecność specyficznych diacylogliceroli, które wskazują na zawartość nielegalnego dodatku oliwy rafinowanej do oliwy extra virgin. W pracy z roku 2020 zastosowano również etap wstępnego oczyszczania techniką SPE z wykorzystaniem wypełnienia krzemionką modyfikowaną diolami. Tak silnie polarne wypełnienie zapewniło selektywność wydzielenia frakcji zawierającej diacyloglicerole, jednak wymagało ono zastosowania przez autorów rozpuszczalnika o szczególnie wysokiej sile elucyjnej, tj. mieszaniny chloroformu i metanolu w stosunku $2: 1 \mathrm{~V} / \mathrm{V}$. Najbardziej interesującą $\mathrm{w}$ omawianej pracy wydaje się jednak zastosowana kolumna Rtx-65TG, posiadająca fazę składającą się w $65 \%$ z fenylopolisiloksanu i w 35\% z metylopolisiloksanu. Kolumna ta zapewnia możliwość oznaczania wszystkich acylogliceroli bez konieczności ich derywatyzacji, co może znacznie przyspieszyć oznaczenie ilościowe. Ma również wysoką odporność termiczną (temperatura pracy do $380^{\circ} \mathrm{C}$ ).

Kolumna Rtx-65TG wydaje się obiecująca do zastosowania w oznaczaniu monoacylogliceroli i diacylogliceroli w hydrorafinacie z procesu co-HVO. W badaniach przydatne były również doświadczenia z pracy własnej dotyczącej wydzielania substancji polarnych na żelu krzemionkowym (Burnus, 2012), które umożliwiły odpowiednie usunięcie matrycy węglowodorowej, zakłócającej oznaczenie zarówno monoacylogliceroli, jak i diacylogliceroli.

\section{Metodyka badań}

W celu wykonania oznaczeń zawartości mono- i diacylogliceroli w hydrorafinatach opracowano metodę własną wykorzystującą techniki chromatografii gazowej i cieczowej i poddano ją walidacji.

Do badań zostały wykorzystane następujące materiały wzorcowe o czystości $>99 \%(\mathrm{~m} / \mathrm{m})$ firmy Sigma Aldrich (Niemcy) oraz Larodan (Szwecja): 1,3-dioleina; 1,3-dinonadekanoina; monononadekanoina; 1-monostearyna; 1-monopalmityna i 1-monooleina. Rozpuszczalniki wysokiej czystości: n-heksan, n-heptan, etanol, izopropanol, tetrahydrofuran pozyskano od firmy J.T. Baker. Do przygotowania próbek techniką chromatografii cieczowej zastosowano następujące rozpuszczalniki: n-heptan cz.d.a., izopropanol cz.d.a.

Wydzielanie frakcji zawierającej monoacyloglicerole oraz diacyloglicerole wykonano przy użyciu kolumny do chromatografii cieczowej wypełnionej żelem krzemionkowym specjalnie zmodyfikowanym dla poprawy procesu wydzielania wymienionych substancji.

Oznaczenie przy użyciu chromatografii gazowej z detekcją płomieniowo-jonizacyjną GC-FID w niniejszej pracy przeprowadzono przy użyciu kolumny do chromatografii gazowej firmy Restek Corporation model Rtx-65TG o wymiarach $30 \mathrm{~m} \times 0,25 \mathrm{~mm}$, z filmem fazy stacjonarnej Rtx-65TG (65\% difenylopolisiloksan, $35 \%$ dimetylopolisiloksan) o grubości $0,1 \mu \mathrm{m}$, stabilnej do temperatury $380^{\circ} \mathrm{C}$. Do oznaczeń monoacylogliceroli oraz diacylogliceroli w mieszaninach węglowodorów wykorzystano chromatograf gazowy z detektorem płomieniowo-jonizacyjnym FID firmy Thermo Electron Corporation model Trace GC Ultra.

W celu prawidłowej identyfikacji czasów retencji poszczególnych acylogliceroli oraz wzorców wewnętrznych - roztwory wzorcowe oznaczanych mono- i diacylogliceroli dozowano w ilości $1 \mu$ do chromatografu gazowego w optymalnych warunkach chromatografii gazowej z detekcją płomieniowo-jonizacyjną GC-FID. Na chromatogramach uzyskanych dla przygotowanych roztworów wzorcowych zidentyfikowano czasy retencji acylogliceroli oraz wzorców wewnętrznych. W celu wyznaczenia zakresu czasów retencji diacylogliceroli badaniu poddano również próbkę FAME pochodzącą z zorganizowanych w roku 2019 badań biegłości IIS w Holandii o nazwie „Biodiesel B100 iis19G02”, o wyznaczonej zawartości diacylogliceroli $0,102 \%(\mathrm{~m} / \mathrm{m})$.

Celem wyznaczenia krzywych wzorcowych dla mono- $i$ diacylogliceroli względem zastosowanych wzorców wewnętrznych oznaczono roztwory wzorców roboczych acylogliceroli. Otrzymane chromatogramy poddano integracji ręcznej i odczytano powierzchnie pików poszczególnych zidentyfikowanych mono- i diacylogliceroli oraz odpowiednich wzorców wewnętrznych.

Analizując uzyskane krzywe regresji wraz z podanymi współczynnikami korelacji liniowej, stwierdzono, że otrzymane współczynniki korelacji przyjmują wartości wyższe niż 0,99 , a zatem zależności liniowe są istotne statystycznie. Uzyskane wartości współczynników korelacji dla zależności liniowej potwierdziły liniowość wskazań detektora FID w zależności od stężenia monoacylogliceroli w zakresie 
pomiarowym od $1,7 \mathrm{mg} / \mathrm{kg}$ do $36,9 \mathrm{mg} / \mathrm{kg}$, a od stężenia diacylogliceroli w zakresie pomiarowym od $1,1 \mathrm{mg} / \mathrm{kg}$ do $23,0 \mathrm{mg} / \mathrm{kg}$.

W celu sprawdzenia wpływu matrycy hydrorafinatu z procesu co-HVO na uzyskiwane wyniki oznaczenia zawartości mono- i diacylogliceroli poddano badaniu frakcję naftową z analogicznego procesu wodorowego HON, bez dodatku oleju roślinnego do wsadu na reaktor. Przy maksymalnej czułości metody stwierdzono obecność jedynie niewielkich pików chromatograficznych w omawianym obszarze, a wyniki kształtowały się znacznie poniżej dolnej granicy zakresu pomiarowego metody, wynoszącego $1,0 \mathrm{mg} / \mathrm{kg}$.

\section{Walidacja metody oznaczania mono- i diacylogliceroli}

Jednym z elementów walidacji nowej metody badawczej jest wyznaczenie granicznych możliwości metody. Granica wykrywalności jest to najmniejsza zmierzona zawartość oznaczanego składnika próbki, na podstawie której można wnioskować o obecności takiego składnika z wystarczającą pewnością statystyczną. Granica wykrywalności liczbowo odpowiada wartości trzech odchyleń standardowych średniej z serii oznaczeń ślepej próby dla sumarycznej zawartości. Z kolei granica oznaczalności to najmniejsza zawartość oznaczanego składnika próbki, która może być oznaczona ilościowo z wystarczającą pewnością statystyczną. Jeżeli dokładność i precyzja są stałe w zakresie stężeń zbliżonych do granicy wykrywalności, granica oznaczalności liczbowo odpowiada wartości sześciu odchyleń standardowych średniej z serii oznaczeń ślepej próby. Wyznaczone granice wykrywalności dla mono- i diacylogliceroli wyniosły odpowiednio: $0,9 \mathrm{mg} / \mathrm{kg}$ i $0,5 \mathrm{mg} / \mathrm{kg}$. Z kolei granice oznaczalności dla mono- i diacylogliceroli były równe: $1,8 \mathrm{mg} / \mathrm{kg}$ i $1,0 \mathrm{mg} / \mathrm{kg}$.

W kolejnym etapie walidacji określono powtarzalność metody poprzez przeanalizowanie szeregu próbek rzeczywistych hydrorafinatów wzbogaconych o mono- i diacyloglicerole w zakresie metody. Dla każdej próbki wykonano trzy oznaczenia.

Obliczono odchylenie standardowe dla wartości średniej, a następnie powtarzalność zgodnie z normą ASTM E 691 według poniższego wzoru:

$$
r_{o b l}=s \cdot 2,8
$$

gdzie: $s$ - odchylenie standardowe.

Uzyskane wartości przedstawiono w tabelach 1 i 2.

Dla wszystkich przebadanych próbek hydrorafinatu wzbogaconego o monoacyloglicerole otrzymana powtarzalność mieściła się w granicach wartości wyznaczonych równaniem $r=0,065 \times \mathrm{C}_{\mathrm{MAG}}$, natomiast $\mathrm{w}$ przypadku diacylogliceroli $r=0,066 \times \mathrm{C}_{\mathrm{DAG}}$

$\mathrm{W}$ ostatnim etapie walidacji nowej metody badawczej wyznaczono niepewność złożoną metody oznaczania mono- i diacylogliceroli w hydrorafinacie z procesu co-HVO. W pierwszej kolejności określono niepewności cząstkowe.

Tabela 1. Wyznaczenie powtarzalności oznaczania monoacylogliceroli

Table 1. Determination of repeatability of monoacylglycerols determination

\begin{tabular}{|c|c|c|c|c|}
\hline \multirow[t]{2}{*}{ Nazwa próbki } & $\begin{array}{c}\text { Wyniki } \\
\text { oznaczeń }\end{array}$ & $\begin{array}{c}\text { Średni wynik } \\
\text { oznaczenia }\end{array}$ & $\begin{array}{l}\text { Odchylenie } \\
\text { standardowe }\end{array}$ & $\begin{array}{c}\text { Powtarzalność } \\
\text { wyznaczona } r \\
\text { wg ASTM E } 691\end{array}$ \\
\hline & \multicolumn{4}{|c|}{$[\mathrm{mg} / \mathrm{kg}]$} \\
\hline \multirow{3}{*}{ Próbka hydrorafinatu $\mathrm{z}$ dodatkiem monoacylogliceroli $\mathrm{nr} 1$} & 1,37 & \multirow{3}{*}{1,36} & \multirow{3}{*}{0,026144} & \multirow{3}{*}{0,073} \\
\hline & 1,38 & & & \\
\hline & 1,33 & & & \\
\hline \multirow{3}{*}{ Próbka hydrorafinatu z dodatkiem monoacylogliceroli $\mathrm{nr} 2$} & 2,87 & \multirow{3}{*}{2,89} & \multirow{3}{*}{0,037441} & \multirow{3}{*}{0,105} \\
\hline & 2,87 & & & \\
\hline & 2,94 & & & \\
\hline \multirow{3}{*}{ Próbka hydrorafinatu $\mathrm{z}$ dodatkiem monoacylogliceroli $\mathrm{nr} 3$} & 6,48 & \multirow{3}{*}{6,50} & \multirow{3}{*}{0,151704} & \multirow{3}{*}{0,425} \\
\hline & 6,36 & & & \\
\hline & 6,66 & & & \\
\hline \multirow{3}{*}{ Próbka hydrorafinatu $\mathrm{z}$ dodatkiem monoacylogliceroli $\mathrm{nr} 4$} & 14,31 & \multirow{3}{*}{14,54} & \multirow{3}{*}{0,198794} & \multirow{3}{*}{0,557} \\
\hline & 14,65 & & & \\
\hline & 14,65 & & & \\
\hline \multirow{3}{*}{ Próbka hydrorafinatu z dodatkiem monoacylogliceroli nr 5} & 36,98 & \multirow{3}{*}{37,17} & \multirow{3}{*}{0,359215} & \multirow{3}{*}{1,006} \\
\hline & 37,58 & & & \\
\hline & 36,94 & & & \\
\hline
\end{tabular}


Tabela 2. Wyznaczenie powtarzalności oznaczania diacylogliceroli

Table 2. Determination of repeatability of diacylglycerols determination

\begin{tabular}{|c|c|c|c|c|}
\hline \multirow[t]{2}{*}{ Nazwa próbki } & $\begin{array}{c}\text { Wyniki } \\
\text { oznaczeń }\end{array}$ & $\begin{array}{l}\text { Średni wynik } \\
\text { oznaczenia }\end{array}$ & $\begin{array}{l}\text { Odchylenie } \\
\text { standardowe }\end{array}$ & $\begin{array}{c}\text { Powtarzalność } \\
\text { wyznaczona } r \\
\text { wg ASTM E } 691\end{array}$ \\
\hline & \multicolumn{4}{|c|}{$[\mathrm{mg} / \mathrm{kg}]$} \\
\hline \multirow{3}{*}{ Próbka hydrorafinatu z dodatkiem diacylogliceroli nr 1} & 1,27 & \multirow{3}{*}{1,25} & \multirow{3}{*}{0,015423} & \multirow{3}{*}{0,043} \\
\hline & 1,24 & & & \\
\hline & 1,25 & & & \\
\hline \multirow{3}{*}{ Próbka hydrorafinatu $\mathrm{z}$ dodatkiem diacylogliceroli $\mathrm{nr} 2$} & 3,20 & \multirow{3}{*}{3,17} & \multirow{3}{*}{0,054597} & \multirow{3}{*}{0,153} \\
\hline & 3,11 & & & \\
\hline & 3,21 & & & \\
\hline \multirow{3}{*}{ Próbka hydrorafinatu $\mathrm{z}$ dodatkiem diacylogliceroli nr 3} & 6,11 & \multirow{3}{*}{6,16} & \multirow{3}{*}{0,145469} & \multirow{3}{*}{0,407} \\
\hline & 6,33 & & & \\
\hline & 6,05 & & & \\
\hline \multirow{3}{*}{ Próbka hydrorafinatu z dodatkiem diacylogliceroli nr 4} & 12,83 & \multirow{3}{*}{12,85} & \multirow{3}{*}{0,060379} & \multirow{3}{*}{0,169} \\
\hline & 12,92 & & & \\
\hline & 12,81 & & & \\
\hline \multirow{3}{*}{ Próbka hydrorafinatu z dodatkiem diacylogliceroli nr 5} & 26,70 & \multirow{3}{*}{26,03} & \multirow{3}{*}{0,589931} & \multirow{3}{*}{1,652} \\
\hline & 25,59 & & & \\
\hline & 25,80 & & & \\
\hline
\end{tabular}

Uwzględniono niepewności cząstkowe związane z pomiarami masy przy sporządzaniu roztworu wzorcowego acylogliceroli, roztworu wzorców wewnętrznych oraz przy ważeniu próbki do badania $u(m)$. Istotne były również niepewności cząstkowe związane z pomiarami objętości $u(V)$ wykonanymi podczas sporządzania roztworu wzorcowego acylogliceroli i roztworu wzorców wewnętrznych, a także przy wydzielaniu frakcji zawierającej acyloglicerole oraz podczas dozowania próbki do chromatografu gazowego.

Analizie poddano także niepewności cząstkowe związane z czystością materiałów wzorcowych $u(P)$ mono- i diacylogliceroli oraz niepewność cząstkową związaną z wyznaczeniem współczynników kierunkowych krzywych wzorcowych monoacylogliceroli $u\left(A_{M A G}\right)$ i diacylogliceroli $u\left(A_{D A G}\right)$.

Jako niepewność związaną z powtarzalnością $u\left(r_{M A G}\right)$, $u\left(r_{D A G}\right)$ metody przyjęto najwyższe odchylenie standardowe wyznaczone podczas oceny powtarzalności metody.

Równania wyrażające niepewność złożoną $u\left(C_{M A G}\right)$ metody oznaczania zawartości monoacylogliceroli oraz $u\left(C_{D A G}\right)$ oznaczania zawartości diacylogliceroli w hydrorafinacie z procesu co-HVO przyjmują postać:

$u\left(C_{M A G}\right)=C_{M A G} \cdot \sqrt{\begin{array}{l}u_{w}^{2}(m)+u_{w}^{2}(V)+u_{w}^{2}(P)+ \\ +u_{w}^{2}\left(A_{M A G}\right)+u_{w}^{2}\left(r_{M A G}\right)\end{array}}$

$$
u\left(C_{D A G}\right)=C_{D A G} \cdot \sqrt{\begin{array}{l}
u_{w}^{2}(m)+u_{w}^{2}(V)+u_{w}^{2}(P)+ \\
+u_{w}^{2}\left(A_{D A G}\right)+u_{w}^{2}\left(r_{D A G}\right)
\end{array}}
$$

Niepewność rozszerzoną metody oznaczania mono- i diacylogliceroli w hydrorafinacie z procesu co-HVO obliczono po uwzględnieniu współczynnika rozszerzenia $k=2$ dla poziomu ufności 95\%. Niepewność rozszerzona metody oznaczania monoacylogliceroli wyniosła $22,4 \%$ wyniku oznaczenia, natomiast dla diacylogliceroli było to $16,2 \%$ wyniku.

\section{Badania hydrorafinatów pod kątem zawartości mono- i diacylogliceroli}

Opracowaną i poddaną walidacji metodę oznaczania monoi diacylogliceroli wykorzystano do badań nad produktami pochodzącymi z procesu HVO oraz z procesu współuwodornienia co-HVO frakcji naftowych i surowców roślinnych. Wsad do reaktora co-HVO stanowiła mieszanina frakcji z destylacji atmosferycznej ropy naftowej A-3 i A-4 z dodatkiem od $5 \%(\mathrm{~m} / \mathrm{m})$ do $7 \%(\mathrm{~m} / \mathrm{m})$ oleju rzepakowego, natomiast wsad do reaktora $\mathrm{HCO}$ - czysty olej rzepakowy. Produkty procesu HVO, jak i procesu współuwodornienia co-HVO nie były do tej pory badane $\mathrm{w}$ zakresie śladowych zawartości mono- i diacylogliceroli. Szczególnie interesująca pod kątem określenia zawartości mono- i diacylogliceroli była próbka 
Tabela 3. Wyniki badań próbek rzeczywistych hydrorafinatów z procesu co-HVO, jak również z procesu HVO

Table 3. The results for real samples of hydro-raffinates from co-HVO and HVO processes

\begin{tabular}{|c|c|c|c|c|}
\hline \multirow[b]{2}{*}{ Lp. } & \multirow[b]{2}{*}{ Próbka } & \multicolumn{3}{|c|}{$\begin{array}{c}\text { Zawartość } \\
{[\mathrm{mg} / \mathrm{kg}]}\end{array}$} \\
\hline & & $\begin{array}{l}\text { monoacyloglicerole, } \\
\mathrm{C}_{\mathrm{MAG}}\end{array}$ & $\begin{array}{c}\text { diacyloglicerole, } \\
\mathrm{C}_{\mathrm{DAG}}\end{array}$ & $\begin{array}{c}\text { triacyloglicerole, } \\
\text { oznaczone wg metody } \\
\text { INiG - PIB 11/2019 }\end{array}$ \\
\hline 1 & Produkt współuwodornienia 10.2019 pr. nr 1 (wsad 5\% OR) & $<1,8(1,4)$ & $<1,1(<0,5)$ & $<5,0$ \\
\hline 2 & Produkt współuwodornienia 10.2019 pr. nr 2 (wsad 7\% OR) & $<1,8(<0,9)$ & $<1,1(<0,5)$ & $<5,0$ \\
\hline 3 & Produkt współuwodornienia 10.2019 pr. nr 3 (wsad 7\% OR) & $<1,8(<0,9)$ & $<1,1(<0,5)$ & $<5,0$ \\
\hline 4 & Produkt współuwodornienia 10.2019 pr. nr 4 (wsad 7\% OR) & $<1,8(<0,9)$ & $<1,1(<0,5)$ & $<5,0$ \\
\hline 5 & Produkt współuwodornienia 10.2019 pr. nr 5 (wsad 7\% OR) & $<1,8(<0,9)$ & $<1,1(<0,5)$ & $<5,0$ \\
\hline 6 & Produkt współuwodornienia 10.2019 pr. nr 6 (wsad 7\% OR) & $<1,8(1,1)$ & $<1,1(<0,5)$ & $<5,0$ \\
\hline 7 & Próbka z procesu HVO 2019 r. (wsad 100\% OR) & $<1,8(1,3)$ & $<1,1(<0,5)$ & $<5,0$ \\
\hline 8 & Produkt współuwodornienia, 2019 r. pr. nr 7 (wsad 5\% OR) & $<1,8(<0,9)$ & $<1,1(<0,5)$ & $<5,0$ \\
\hline 9 & $\begin{array}{l}\text { Produkt współuwodornienia z obecnym nieprzereagowanym } \\
\text { olejem roślinnym (triacyloglicerole), } 2020 \mathrm{r} \text {. }\end{array}$ & $<1,8(1,3)$ & $<1,1(0,8)$ & 60,0 \\
\hline
\end{tabular}

z procesu co-HVO, która zawierała nieprzereagowane triacyloglicerole TAG w ilości $60 \mathrm{mg} / \mathrm{kg}$. Uzyskane wyniki badań przedstawiono w tabeli 3, w której zamieszczono również wyniki zawartości triacylogliceroli oznaczone według metody INiG - PIB.

Wszystkie badane produkty procesu współuwodornienia oraz próbka z procesu HVO pochodzące z instalacji przemysłowych z roku 2019 wykazywały zawartości monoacylogliceroli oraz diacylogliceroli poniżej granicy oznaczalności metody.

W przypadku pięciu badanych próbek hydrorafinatów (tabela 3 , poz. $2,3,4,5,8)$ nie stwierdzono nawet śladowych zawartości mono- i diacylogliceroli. Wyniki powierzchni pików monoacylogliceroli i diacylogliceroli znajdowały się poniżej granicy wykrywalności opracowanej i zwalidowanej metody. Próbki te nie zawierały również triacylogliceroli TAG i wolnych kwasów tłuszczowych WKT, co stwierdzono we wcześniej wykonanych badaniach.

Poza wymaganym zgodnie rozporządzeniem Ministra Klimatu (Dz.U. z 2020 r. poz. 1141) badaniem strumienia procesowego na zawartość triacylogliceroli TAG - stwierdzone w niniejszych badaniach wartości poniżej granicy wykrywalności mono- i diacylogliceroli stanowią dodatkowe potwierdzenie prawidłowości zachodzenia procesu współuwodornienia co-HVO oraz HVO.

Chromatogram z oznaczenia próbki na zawartość mono- i diacylogliceroli przedstawiono na rysunku 3.
W przypadku czterech próbek poddanych badaniom (tab. 3, poz. 1, 6, 7, 9) stwierdzono niewielką zawartość monoacylogliceroli na śladowym, wykrywalnym poziomie około 1,3$1,4 \mathrm{mg} / \mathrm{kg}$. Wśród tych próbek była zarówno próbka z procesu HVO, jak i o podwyższonej zawartości nieprzereagowanych triacylogliceroli.

Powyższe wyniki wskazują na możliwość występowania monoacylogliceroli na bardzo niskim, ale wykrywalnym poziomie, szczególnie dla próbek z procesu hydrokonwersji z zastosowaniem wsadu do reaktora o podwyższonej zawartości surowca roślinnego. Podobną obserwację poczyniono

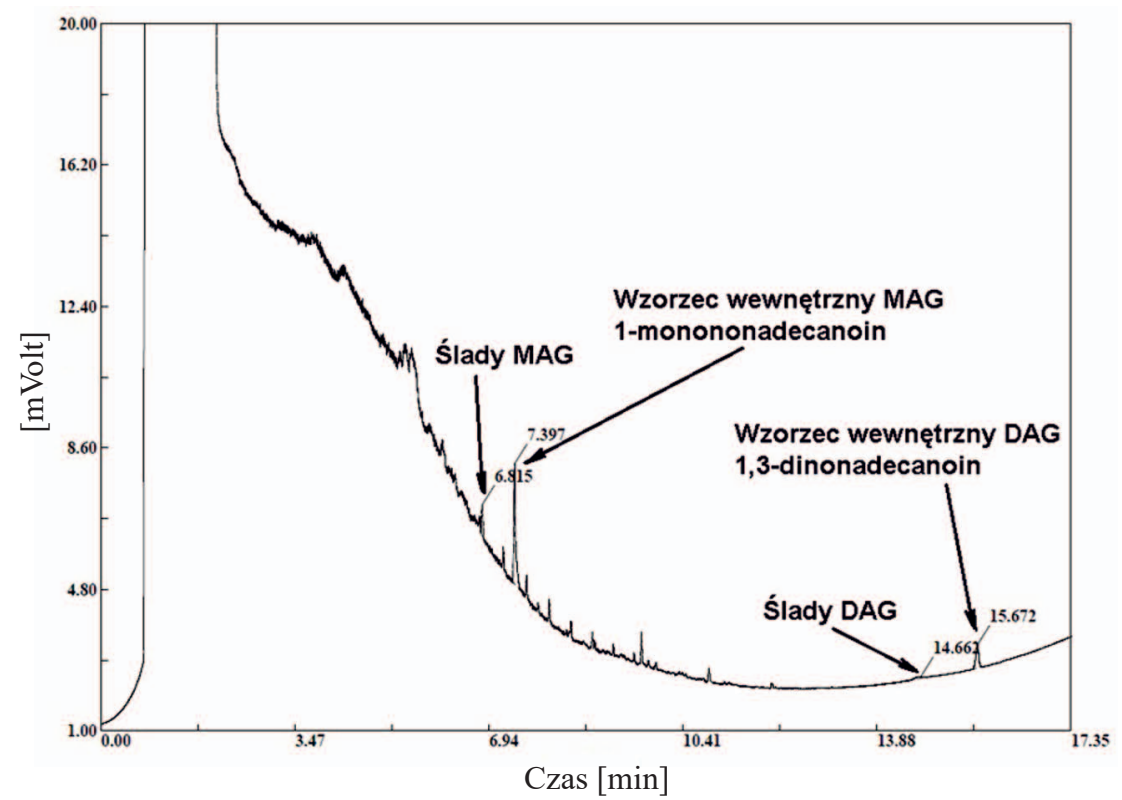

Rys. 3. Chromatogram z oznaczenia próbki hydrorafinatu na zawartość monoi diacylogliceroli

Fig. 3. Chromatogram from the analysis of mono- and diacylglycerols content in a hydro-raffinate sample 
w przypadku próbki charakteryzującej się obecnością niecałkowicie przereagowanego surowca roślinnego. W przypadku tej próbki (tab. 3, poz. 9), o podwyższonej zawartości triacylogliceroli TAG, poza wykryciem monoacylogliceroli na poziomie około $1,3 \mathrm{mg} / \mathrm{kg}$ zaobserwowano dodatkowo wykrywalne zawartości diacylogliceroli $(0,8 \mathrm{mg} / \mathrm{kg})$, co świadczy o ich obecności w strumieniu procesowym.

Badane strumienie procesowe były wytworzone z czystych komponentów tłuszczowych i (poza częścią węglowodorową) zawierały głównie triacyloglicerole TAG. W przypadku zastosowania innych surowców do procesu współuwodornienia co-HVO lub HVO, szczególnie o podwyższonej zawartości wolnych kwasów tłuszczowych oraz mono- i diacylogliceroli, wskazane jest wykonywanie badań wszystkich acylogliceroli (również mono- i di-) w celu dodatkowej kontroli procesu współuwodornienia. Metoda opracowana w INiG - PIB może zatem posłużyć do przeprowadzenia badań strumieni procesowych z instalacji współuwodornienia odpadowych surowców roślinnych, w tym zużytego oleju roślinnego (UCO), pod kątem śladowych zawartości nasyconych monoacylogliceroli.

\section{Dyskusja i podsumowanie}

Przy wykorzystaniu zestawu materiałów wzorcowych acylogliceroli oraz odpowiedniej kolumny do chromatografii gazowej z fazą Rtx-65TG, z zastosowaniem oczyszczania techniką chromatografii cieczowej, możliwe było opracowanie metody oznaczania śladowych zawartości mono- i diacylogliceroli w hydrorafinacie z wysoką czułością (granica oznaczalności $1,8 \mathrm{mg} / \mathrm{kg}$ dla monoacylogliceroli oraz $1,1 \mathrm{mg} / \mathrm{kg}$ dla diacylogliceroli).

Opracowaną metodę wykorzystano do badań hydrorafinatów z procesu co-HVO i HVO pod kątem zawartości mono- i diacylogliceroli na śladowym poziomie, znacznie poniżej $10 \mathrm{mg} / \mathrm{kg}$.

Wyniki zawartości mono- i diacylogliceroli poniżej granicy oznaczalności dla próbek hydrorafinatów, które nie zawierały również triacylogliceroli TAG i wolnych kwasów tłuszczowych WKT, stanowią dodatkowe potwierdzenie prawidłowości zachodzenia procesów współuwodornienia co-HVO oraz HVO. Co szczególnie istotne, stanowią one dodatkową ocenę jakości produktu z reaktora hydrokonwersji co-HVO i prawidłowości jego działania.

Wykrycie śladowych zawartości mono- i diacylogliceroli dla próbki charakteryzującej się podwyższoną zawartością triacylogliceroli (niecałkowicie przereagowanego surowca roślinnego) wskazuje jednak na możliwość występowania $\mathrm{w}$ produkcie z procesu co-HVO również niewielkich ilości monoacylogliceroli i diacylogliceroli. Wskazane jest zatem wykonywanie badań tych śladowych substancji pochodzenia tłuszczowego w produkcie współuwodornienia. Takie badania są szczególnie zalecane w przypadku zastosowania wyższych udziałów surowca roślinnego we wsadzie do reaktora hydrokonwersji oraz przy stosowaniu nietypowych surowców roślinnych - w tym o podwyższonej zawartości wolnych kwasów thuszczowych oraz mono- i diacylogliceroli. Śladowe zawartości mono- i diacylogliceroli na wykrywalnym poziomie stwierdzono również w produkcie z procesu HVO, co wskazuje, że kontrola ich zawartości w tego typu produkcie jest wskazana.

Produkty współuwodornienia średnich destylatów i surowców tłuszczowych różnego pochodzenia (w tym odpadowych) będą stopniowo zyskiwały na znaczeniu z uwagi na możliwość łatwego wkomponowania podczas wytwarzania paliwa do silników o zapłonie samoczynnym. Rozporządzenie Ministra Klimatu w sprawie zawartości biokomponentów powstałych w wyniku współuwodornienia (Dz.U. z 2020 r. poz. 1141) wprowadziło wymaganie maksymalnej zawartości triacylogliceroli na poziomie $10 \mathrm{mg} / \mathrm{kg}$ w produkcie z tego procesu.

W przypadku zastosowania innych surowców tłuszczowych w procesie współuwodornienia co-HVO lub HVO, szczególnie odpadowych (UCO), wskazane jest wykonanie badań strumieni procesowych z instalacji współuwodornienia pod kątem śladowych zawartości nasyconych monoacylogliceroli, co umożliwia opracowana w INiG - PIB metoda.

Artykuł powstał na podstawie pracy badawczej pt. Badania nad oznaczaniem śladowych składników lipidowych $w$ mieszaninach weglowodorów technikami chromatograficznymi - praca INiG - PIB na zlecenie MNiSW; nr zlecenia: 0090/TA/2020, nr archiwalny: DK-4100-0078/2020.

\section{Literatura}

Alberdi-Cedeño J., Ibargoitia M.L., Cristillo G., Sopelana P., Guillén M.D., 2017. A new methodology capable of characterizing most volatile and less volatile minor edible oils components in a single chromatographic run without solvents or reagents. Detection of new components. Food Chemistry, 221: 1135-1144. DOI: 10.1016/j.foodchem.2016.11.046.

Alleman T.L., Christensen E.D., Moser B.R., 2019. Improving biodiesel monoglyceride determination by ASTM method D6584-17. Fuel, 241: 65-70. DOI: 10.1016/j.fuel.2018.12.019.

Ashraf-Khorassani M., Yang J., Rainville P., Jones M.D., Fountain K.J., Isaa G., Taylor L.T., 2015. Ultrahigh performance supercritical fluid chromatography of lipophilic compounds with application to synthetic and commercial biodiesel. Journal of Chromatography B, 983-984: 94-100. DOI: 10.1016/j.jchromb.2014.12.012.

Burnus Z., 2012. Badania nad oznaczaniem glikozydów sterolowych (SG) oraz nasyconych monoacylogliceroli (SMG) w oleju napędowym z dodatkiem estrów metylowych kwasów tłuszczowych przy wykorzystaniu techniki chromatografii gazowej. Archiwum Instytutu Nafty i Gazu - Państwowego Instytutu Badawczego, Kraków, nr archiwalny: DK-4100-36/2012.

Burnus Z., 2019. Opracowanie metody oznaczania składników lipidowych w mieszaninach węglowodorów technikami chromato- 
graficznymi. Archiwum Instytutu Nafty i Gazu - Państwowego Instytutu Badawczego, Kraków, nr archiwalny DK-4100-144/2019.

Chemical Book: 1,3-Diolein, <https://www.chemicalbook.com/ ChemicalProductProperty_EN_CB5179215.htm> (dostęp: 12.01.2021).

Chemical Book: 1,3-Distearin, <https://www.chemicalbook.com/ ChemicalProductProperty EN CB8378929.htm> (dostęp: 12.01.2021).

Chemical Book: Glyceryl Monooleate, <https://www.chemicalbook. com/chemicalproductproperty en cb2757258.htm> (dostęp: 12.01.2021).

Chemical Book: Glyceryl Monostearate, <https://www.chemicalbook. com/chemicalproductproperty_en_cb7234695.htm> (dostęp: 12.01.2021).

Destaillats F., Cruz-Hernandez C., Nagy C., Dionisi F., 2010. Identification of monoacylglycerol regio-isomers by gas chromatography-mass spectrometry. Journal of Chromatography A, 1217: 1543-1548. DOI: 10.1016/j.chroma.2010.01.016.

Flanagan G., Andrianova A., Casey J., Hellrung E., Diep B., Seames W., Kubatova A., 2019. Simultaneous high-temperature gas chromatography with flame ionization and mass spectrometric analysis of monocarboxylic acids and acylglycerols in biofuels and biofuel intermediate products. Journal of Chromatography A, 1584: 165-178. DOI: 10.1016/j.chroma.2018.11.044.

Gomez-Coca R.B., de Carmen Perez-Camino M., Bendini A., Gallina Toschi T., Moreda W., 2020. Olive oil mixtures. Part two: Detection of soft deodorized oil in extra virgin, olive oil through diacylglycerol determination. Relationship with free acidity. Food Chemistry, 330: 127226. DOI: 10.1016/j.foodchem.2020.127226.

Holcapek M., Jandera P., Zderadicka P., Hruba L., 2003. Characterization of triacylglycerol and diacylglycerol composition of plant oils using high-performance liquid chromatography - atmospheric pressure chemical ionization mass spectrometry. Journal of Chromatography A, 1010: 195-215. DOI: 10.1016/ s0021-9673(03)01030-6.

Jakkula J., Niemi V., Nikkonen J., Purola V., Mylloya J., Aalto P., Lethonen J., 2004. Process for producing a hydrocarbon component of biological origin. Patent EP 1396531.

Jęczmionek Ł., 2011. Odpadowe oleje roślinne jako surowiec do otrzymywania biokomponentów II generacji. Nafta-Gaz, 10: 742-748.

Jęczmionek Ł., Lubowicz J., 2009. Hydrokonwersja olejów i tłuszczów naturalnych do węglowodorów. Nafta-Gaz, 1: 29-36.

Lubowicz J., 2016. Wpływ biokomponentu otrzymanego w wariancie co-processing na właściwości oleju napędowego. Prace Naukowe Instytutu Nafty i Gazu - Państwowego Instytutu Badawczego, 208: 1-172. DOI: 10.18668/PN2016.208.

Mylloya J., Aalto P., Harlin E., 2007. Process for the manufacture of diesel range hydrocarbons. Patent EP 1741767.

Perez-Camino M.C., Moreda W., Cert A., 1996. Determination of diacylglycerol isomers in vegetable oils by solid-phase extraction followed by gas chromatography on a polar phase. Journal of Chromatography A, 721: 305-331.

Prados C.P., Rezende C.R., Batista L.R., Alves M.L.R., Filho N.R.A., 2012. Simultaneous gas chromatographic analysis of total esters, mono-, di- and triacylglycerols and free and total glycerol in methyl ethyl biodiesel. Fuel, 96: 476-481. DOI: 10.1016/j. fuel.2011.11.060

Teng F., Reis M.G., Yang L., Ma Y., Day L., 2019. In-depth lipidomie analysis of tri-, di-, and mono-acylglycerols released from milk fat after in vitro digestion. Food Chemistry, 297: 124976. DOI: 10.1016/j.foodchem.2019.124976.

Zhou Q., Gao B., Zhang X., Xu Y., Shi H., Yu L., 2014. Chemical profiling of triacylglycerols and diacylglycerols in cow milk fat by ultra-performance convergence chromatography combined with a quadrupole time-of-flight mass spectrometry. Food Chemistry, 143: 199-204. DOI: 10.1016/j.foodchem.2013.07.114.

Zhu H., Clegg M.S., Shoemaker C.F., Wang S.C., 2013. Characterization of diacylglycerol isomers in edible oils using gas chromatography-ion trap electron ionization mass spectrometry. Journal of Chromatography A, 1304: 194-202. DOI: 10.1016/j. chroma.2013.06.058.

\section{Akty prawne i dokumenty normatywne}

Rozporządzenie Ministra Energii z dnia 25 maja 2016 r. w sprawie wymagań jakościowych dla biopaliw ciekłych, Dz.U. z 2016 r. poz. 771.

Rozporządzenie Ministra Energii z dnia 14 października 2016 r. w sprawie metod badania jakości biopaliw ciekłych, Dz.U. z 2016 r. poz. 1802.

Rozporządzenie Ministra Klimatu z dnia 24 czerwca 2020 r. w sprawie zawartości biokomponentów powstałych w wyniku współuwodornienia, Dz. U. z 2020 r. poz. 1141.

ASTM D6584-17 Standard Test Method for Determination of Total Monoglycerides, Total Diglycerides, Total Triglycerides, and Free and Total Glycerin in B-100 Biodiesel Methyl Esters by Gas Chromatography.

ASTM E 691-19e1 Standard Practice for Conducting an Interlaboratory Study to Determine the Precision of a Test Method.

PN-EN 14103:2004 Produkty przetwarzania olejów i tłuszczów Estry metylowe kwasów tłuszczowych (FAME) - Oznaczanie zawartości estrów i estru metylowego kwasu linolenowego (norma wycofana).

PN-EN 14105:2012 Produkty przetwarzania olejów i tłuszczów Estry metylowe kwasów tłuszczowych (FAME) - Oznaczanie zawartości wolnego i ogólnego glicerolu oraz mono-, di- i triacylogliceroli.

PN-EN 15779+A1:2013-12 Przetwory naftowe oraz produkty przetwarzania olejów i thuszczów - Estry metylowe kwasów tłuszczowych (FAME) do silników o zapłonie samoczynnym (Diesla) - Oznaczanie estrów metylowych wielonienasyconych kwasów thuszczowych ( $\geq 4$ wiązania podwójne) (PUFA) metodą chromatografii gazowej.

PN-EN ISO 18395:2008 Oleje i tłuszcze roślinne oraz zwierzęce - Oznaczanie monoacylogliceroli, diacylogliceroli, triacylogliceroli i glicerolu metodą wysokosprawnej chromatografii sitowej (HPSEC).

PN-EN ISO 29822:2014-06 Oleje i tłuszcze roślinne - Izomeryczne diacyloglicerole - Oznaczanie względnych ilości 1,2- i 1,3-diacylogliceroli.

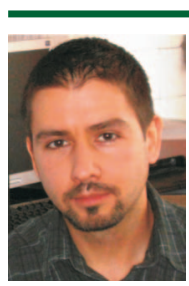

Dr inż. Zygmunt BURNUS

Asystent w Zakładzie Analiz Naftowych Instytut Nafty i Gazu - Państwowy Instytut Badawczy ul. Lubicz 25 A

31-503 Kraków

E-mail:zygmunt.burnus@inig.pl

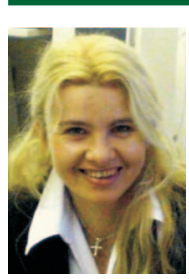

Mgr inż. Agnieszka WIECZOREK

Specjalista badawczo-techniczny w Zakładzie Analiz Naftowych; kierownik Pracowni Analiz Instrumentalnych

Instytut Nafty i Gazu - Państwowy Instytut Badawczy ul. Lubicz 25 A, 31-503 Kraków

E-mail: agnieszka.wieczorek@inig.pl 